\title{
INFLUENCE OF ADVERTISMENTS ON CHANGES IN THE URBAN STRUCTURE OF CITES ON THE EXAMPLE OF POZNAN
}

\author{
Agata BONENBERG ${ }^{1}$, \\ Poznan University of Technology, Faculty of Architecture, Poznan, Poland
}

\begin{abstract}
The article presents the results of studies on the influence of outdoor advertisements on the activation of selected areas in the spatial structure of the city of Poznan. The contents of advertisements were analyzed in terms of the places which advertisements placed on signs, billboards and advertising displays located in public spaces direct us to. The results of studies indicated that the majority of advertisements located in the city center of Poznań promote suburban locations, encouraging its inhabitants to make use of trade and services outside of the strict city center. At the same time, it was indicated that outside advertisements due to the content of the advertising message are a factor degrading the city center, directing potential customers away into the suburbs. In practice, it was noted that the phenomenon significantly decreases the effectiveness of actions directed towards revitalizing the city center and the urban activation of this region.
\end{abstract}

Keywords: outdoor advertising, public space, urban activation

\section{INTRODUCTION}

Outside advertising has become an integral part of public spaces within modernday cities. It takes up the best exhibited places, such as the intersections of roads, building facades and roofs, and representative areas. The urban landscape is filled with advertising displays, billboards, and advertising columns. This type of marketing is based on "visual consumption" and aimed at drawing the

\footnotetext{
${ }^{1}$ Corresponding author: Poznan University of Technology, Faculty of Architecture, Nieszawska st 13C, 61-021 Poznan, Poland, e-mail: bonagata@wp.pl, tel.+48616653260
} 
attention of as many inhabitants as possible to given products and directing potential clients to places where these products are sold.

Property owners and managers view the advertisements on their buildings as an additional source of income. Outdoor advertisements in public space surround us from every direction, creating a specific visual landscape which we are forced to look at, even if we do not wish to.

As opposed to other forms of advertising, for example TV commercials or press advertisements, we cannot escape outdoor advertising and are condemned to it whenever we are in the public spaces of cities.

Advertisers are well aware of this dependency. For advertising companies, the mass and wide reach of outdoor advertising is its greatest asset. This is why outdoor advertising is considered to be one of the most effective types of advertising mediums [2]. The advertising message it carries is persuasive and effective. It's wide-reaching and long-lasting effect increases the chance of the message being remembered by its recipients. This transfer is characterized by a high frequency of visual contact by placement in many areas of the city, thanks to which it quickly targets potential clients. Advertisers stress that this type of advertising works very well in city centers, as outdoor advertising affects client subconsciously during their everyday activities - people view advertisements as they are walking down the street, driving their car to work, participating in cultural, sport and recreational activities, or shopping.

The following can be read in the offers of companies specializing in this type of marketing, "outdoor advertising is a medium of great potential, with an attractive and original means of communication. Its reception is natural and direct, thanks to which it can successfully compete with other mediums. Recipients come into contact with outdoor advertising when they spend time outside the house in urban space, under circumstances in which they usually anticipate stronger contact with the environment than at home or work" [4].

On the other hand, there is growing criticism of outdoor advertising. It has been emphasized that outdoor advertisements destroy the compositional values of urban interiors and blur the readability of city structures. The negative influence of advertisements on landscape values of cities is described as visual pollution.

As observed by Purice [6], the main reasons behind this phenomenon are:

- administrative negligence (city authorities losing control over the visage of public space),

- unprofessional approach to urban advertising, resulting from the lack of knowledge regarding merchandising. 
Czyński and Ostrowski [5] list the following reasons behind the low efficiency of battling the phenomenon of visual pollution:

- the lack of legal regulations which would make it possible for local authorities to effectively control the advertising chaos,

- relaxed legalization procedures for advertising companies,

- the dispersion of responsibility of decision-making authorities,

- conflicts of interest connected with placing advertisements on the facades of buildings and in public spaces.

Bonenberg [1] devised an original method of diagnosing the phenomenon of visual pollution in an urban landscape using Google Street View technology. The studies conducted in 2013 made it possible to identify 687 places that drastically destroy visual order in the city center of Poznań [7].

In urban analyses, relatively little attention is given to the content of advertisements, which have a significant communicative influence. Seen in this perspective, outdoor advertisements are a type of medium which serves to convey selected information. This function of advertisements is as old as urban structures themselves. Over centuries it has accompanied trade and services located in cities. It took on different forms, but was always aimed at drawing customers and clients to given areas of the city, the effect of which was the urban activation of these regions [3].

While the form and composition of outdoor advertising in urban structures has lived to see numerous (mostly critical) scientific works, advertising content and semantic meaning is given marginal significance in literature on the topic. The presented studies serve to fill this gap and are aimed at analyzing the content of advertisements in city centers in terms of which regions of cities they direct the recipients to.

\section{RESEARCH}

The studies concern the relationship between advertising content and the spatial reality which this content relates to. In this sense, semantic functions of the advertisements cover relationships between the content of the advertising message and the place in the urban structure which the advertising content indicates.

The studies are based on the assumption that the livability of the urban structure depends on the amount of clients purchasing goods and services in selected areas of the city. It is to these areas that they are directed to using advertisements placed in public spaces. Thanks to the accumulation of capital derived from trade and services, the urban activation of individual areas of the city takes place. 
The conducted studies focused on finding answers to the following questions:

- Does the semantic content of advertisements located along roads leading to the city center emphasize its central function in the urban structure of Poznan by directing potential customers to this region?

- Do advertisements located in the city center cause the dispersion of functional activity by directing clients to the suburbs?

It should be noted that the subject of the study was not the esthetic content of advertisements but their semantic content regarding the connection of the location of the advertisement with the area to which it directs the potential client.

The studies differentiated between the following types of advertisements:

- Leading (directing),

- Locating,

- Promoting.

Directing advertisements are ones that are located in a given place but direct potential customers to another, often distant areas of the city or its suburbs. An example of such is an advertisement located in the city center, encouraging clients to pay a visit to a supermarket located in its suburbs.

Locating advertisements are situated in places which their content refers to. An example of such is an advertising sign near the entrance to a hair salon informing people that this is where the hairdresser's is located.

Promoting advertisements are such whose content is not connected with any given location. These usually take the form of large billboards advertising products of global brands (washing detergents, cosmetics, cars), emphasizing only the values of the advertised products. This type of advertisement is neutral in terms of promoting any given location in the city.

Next, a division was made based on the size of the advertisements. Three different size categories were selected: L (large), M (medium), S (small).

Such a division refers to connecting the size of the advertisement with the scale of a person. Small advertisements are ones whose scale is smaller than a person. Medium advertisements refer to a scale comparable to that of a person's figure, whereas large advertisements are many times larger than the scale of a person.

Further classification regarded the subject matter of the advertisement. The following subject groups were differentiated between:

- $\quad$ trade $(\mathrm{T})$

- culture (C)

- public service advertising (PS)

- hotels $(\mathrm{H})$

- restaurants (R)

- $\quad$ sport (S) 
- $\quad$ services (SR)

The studies were carried out in the area of Poznan over the years 2012-2014. Students of the Faculty of Architecture of the Poznan Technical University participated in the field survey used to gather analytical material. The study sample covered 1,515 advertisements (i.e. $80 \%$ of all surveyed cases), characterized by the fact that their content could be read from a distance of over $30 \mathrm{~m}$. These were advertisements located in the area of the Poznań city center according to borders set out in the study of land use conditions and directions.

Apart from this, three areas outside of the city center were randomly selected, and analogical studies based on a comparable study sample carried out to enable comparison.

The studies made use of an urban survey in connection with the geolocation of the identified advertisement displays.

The following methodological steps were taken:

a) determining the location of the outdoor advertisement (address and geolocation data), photographic inventory.

b) analysis of advertising contents: classification / categorization of advertisement into a given group,

c) localization of place to which the advertising content directs the recipient (address and geolocation data),

d) marking the locations of advertisements on the map and areas to which they direct clients,

e) graphic and tabular interpretation of the obtained results.

\section{STUDY DOCUMENTATION}
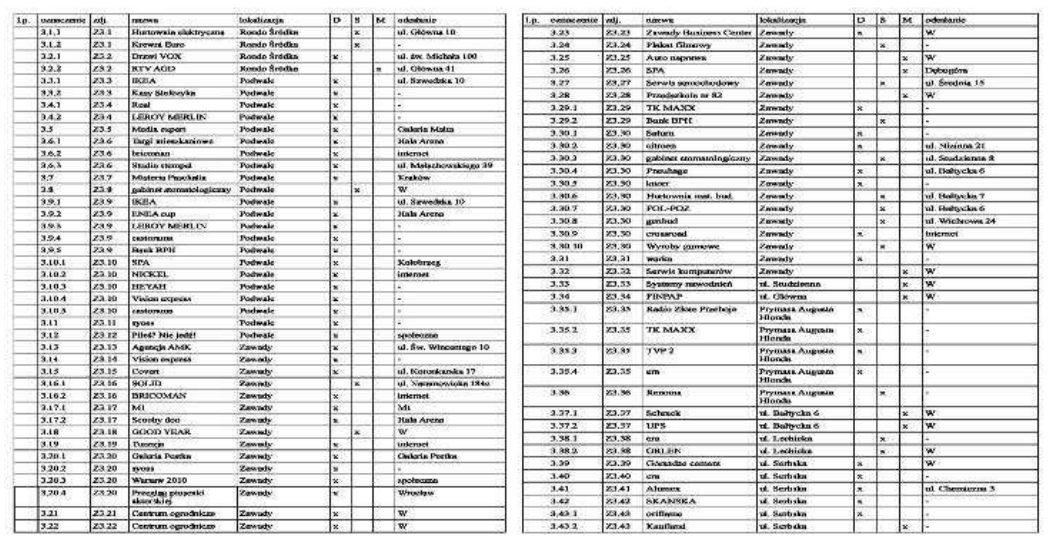

Fig. 1. Fragment of compilation describing the location of an advertisement, its size, subject-matter characteristics and location which the advertising content is directed to 

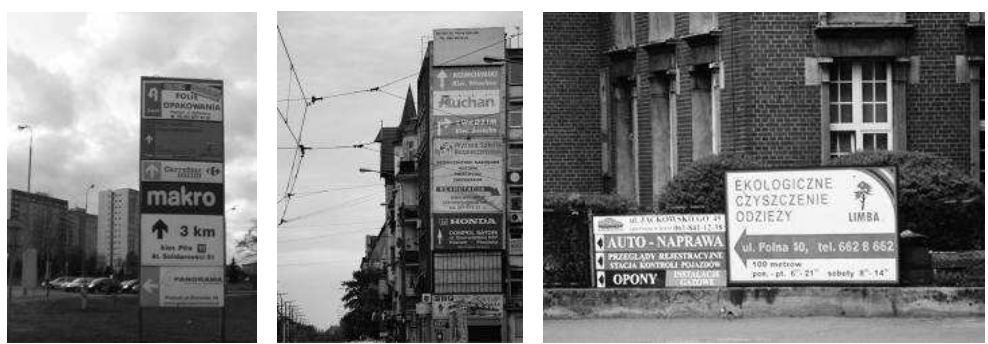

Fig. 2. Photographic documentation of analyzed advertisements located in the city center of Poznań. Examples of leading (directing) advertisements
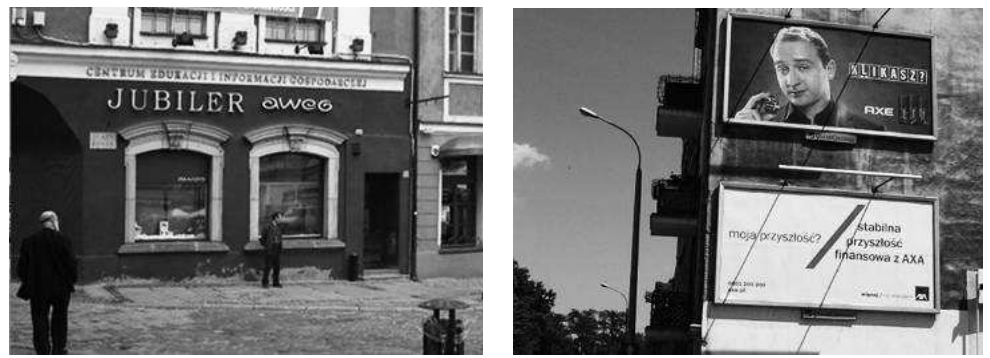

Fig. 3. Photographic documentation of analyzed advertisements located in the city center of Poznań. On the left - locating advertisement (advertising signboard over jeweler's shop), on right - promoting advertisement (does not direct to any location in the city)

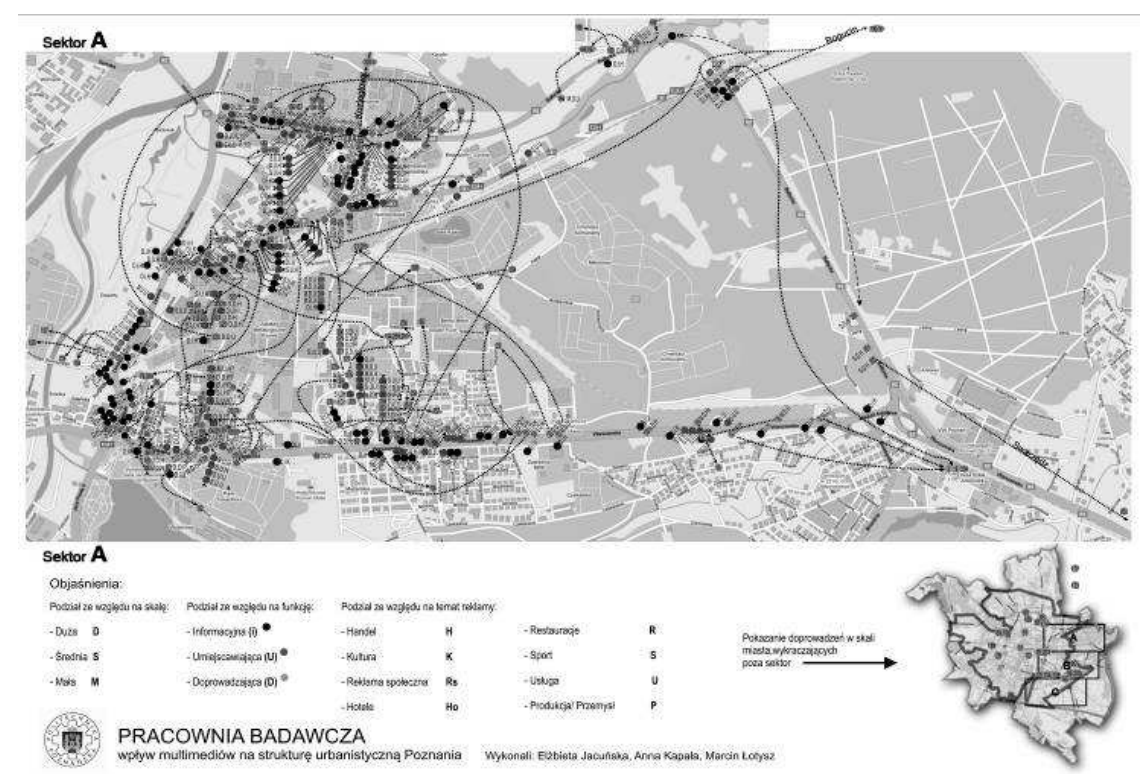

Fig. 4. Example of graphic sheet used to locate the studied advertisements. Eastern part of the city center of Poznań (sector A) 



Fig. 5. Graphical analysis of study results conducted in Poznań over the years 2012-2014. Maps with marked locations of advertisements and places which they direct clients to.

\section{CONCLUSIONS}

As shown by the studies, $64 \%$ of large advertisements located in the city center direct clients to areas outside of the center of Poznan, which reflects the tendency of the functional dispersion of the city. The content of merely $36 \%$ of advertisements draws attention to a service location in the city center.

In suburban areas, this proportion was found to be 54 and 46 , with the majority of locating advertisements, though only $15 \%$ of the directing advertisements steer the attention of potential clients to the city center, and the remaining $85 \%$ to other suburban areas. The subject matter structure of the advertisements was as follows:

\begin{tabular}{|c|c|}
\hline trade $(\mathrm{T})$ & $63 \%$ \\
\hline culture (C) & $2 \%$ \\
\hline public service advertising (PS) & $4 \%$ \\
\hline hotels (HO) & $6 \%$ \\
\hline restaurants $(\mathrm{R})$ & $8 \%$ \\
\hline sport $(\mathrm{S})$ & 49 \\
\hline other services (S) & $13^{c}$ \\
\hline
\end{tabular}

The low percentage of advertisements promoting culture demands attention (information regarding cultural goods, memorial sites, monuments), as it has a significant role in drawing tourists to the city center. This is most certainly the effect of the negligence of city authorities who could obtain funds for promoting such areas through proper cooperation with commercial advertisers. 
The results of studies show that the majority of large advertisements located in the city center of Poznan promote outlying locations, encouraging residents to make use of trade and services found outside the strict city center.

A fundamental problem is the lack of understanding regarding the value and significance of information broadcast contained in outdoor advertising in activating the city center of Poznan and thus the loss of control over the "media landscape" of public space which follows. The identified phenomenon of "directing" residents who are in the city center to make use of services and trade located in the outskirts weakens efforts aimed at the integrated revitalization of the Poznań city center.

\section{REFERENCES}

1. Bonenberg W.: A Method of Assessing Public Space Attractiveness with use of Google Maps. Case of Poznan MA, Advances in Human Factors and Sustainable Infrastructure, $5^{\text {th }}$ AHFE, 7(2014) 119-127.

2. Bris A., Bruke P.: Społeczna historia mediów. Tłumaczenie Jedliński J., Wydawnictwo Naukowe PWN, Warszawa 2010.

3. Britnell R.H.: The Proliferation of Markets in England, The Economic History Review. Volume 34, Issue 2(1981) 209- 220.

4. Cityboard Media.: Reklama zewnętrzna, http://cityboard.pl/pl/reklamazewnetrzna, styczeń 2015.

5. Czyński M. Ostrowski M.: Reklama $w$ przestrzeni publicznej miasta. Przestrzeń i forma nr. 16, (2011) 213-228.

6. Purice S.: Visual Pollution: A New Axiological Dimension of Marketing? The Annals of the University of Oradea. Economic Sciences, TXXI, Issue 2(2012) 820-826.

7. Regimowicz N.: Witryny sklepowe jako czynnik aktywizacji urbanistycznej ulicy - na przyktadzie śródmieścia Poznania, Rozprawa doktorska, promotor Bonenberg W., Politechnika Poznańska, Poznań 2013.

\section{WPŁYW REKLAM NA ZMIANY STRUKTURY URBANISTYCZNEJ MIAST NA PRZYKŁADZIE POZNANIA}

\section{Streszczenie}

W artykule zostały przedstawione wyniki badań dotyczących wpływu reklam zewnętrznych (Outdoor) na aktywizację wybranych obszarów w strukturze przestrzennej 
Poznania. Przeanalizowano treści reklamowe w aspekcie miejsc, do których odsyłaja ogłoszenia zamieszczane na szyldach, billboardach tablicach reklamowych umieszczonych $\mathrm{w}$ przestrzeniach publicznych. Wyniki badań wykazały, że większość reklam zlokalizowanych w śródmieściu Poznania promuje lokalizacje peryferyjne, zachęcając mieszkańców do korzystania z handlu i usług znajdujących poza obszarem ścisłego centrum. Tym samym wskazano, że reklamy zewnętrzne ze względu na treść komunikatu reklamowego są czynnikiem deprecjonującym obszar śródmieścia, „wyprowadzając” potencjalnych klientów na peryferia. W praktyce, zauważone zjawisko w istotny sposób obniża efektywność działań mających na celu rewitalizacje śródmieścia i aktywizację urbanistyczną tego rejonu.

Słowa kluczowe: reklama zewnętrzna, przestrzeń publiczna, aktywizacja urbanistyczna

Editor received the manuscript: 28.11 .2014 
